IAN D. BRYANT:

\title{
LOESS DEPOSITS IN LOWER ADVENTDALEN, SPITSBERGEN
}

\begin{abstract}
Bryant, Ian D., 1982: Loess deposits in lower Adventdalen, Spitsbergen. Polar Research 2: 93-103.

Aeolian deposits are described in terms of their areal distribution, sedimentary and pedological characteristics. These deposits, which have accumulated at the valley margins, result from deflation of fluvian sediments deposited in the valley bottom. Fine horizontal lamination in the upper horizons is tentatively attributed to winnowing of primary depositional units following partial cementation by salt precipitates. This stratification breaks down at depth and is replaced by a gleyed horizon, resulting from drainage impedance by permafrost. Proximal aeolian accumulations on fluvially inactive areas of the valley bottom may typify many other valleys in Spitsbergen.

Ian D. Bryant, Department of Geography, University of Reading, Whiteknights Road, Reading RG6 $2 A U$, England.

\section{Introduction}

The Adventelva occupies a broad valley some $27 \mathrm{~km}$ long in north Nordenskiöld Land located at approximately $78^{\circ} \mathrm{N}$ which drains into Adventfjorden immediately northeast of Longyearbyen. During the winter months the river is frozen and the valley covered by a blanket of snow, but in spring, normally during May, the snow melts and the river rapidly reforms, discharging much of the accumulated winter's precipitation in a single flood event. Discharge remains high throughout the summer due to inputs of glacial meltwater derived from the many glaciers within the drainage basin. Thus the hydrologic regime of the Adventelva is of an 'arctic proglacial' character (of CHURCH 1974) and as a corollary is characterised by stage fluctuations throughout the summer months. The
\end{abstract}


high glacially derived discharge contribution results in high sediment loads, some of which are deposited in a complex variety of bar forms in the fluvially active regions of the valley bottom. Other geomorphic units in the valley are alluvial fans associated with tributary valley systems, elevated abandoned fluvial tracts (level 2 of WILLIAMS and RUST 1969) and low terraces. The distribution of these elements was mapped by a combination of field survey and aerial photograph interpretation (Fig.1).

This paper describes the materials which comprise the low inter-fan terrace units on the flanks of the valley and offers an explanation of their genesis. These materials have previously been described by FEDEROFF (1966) and PORTMANN (1969). Federoff attributed the materials to alluvial deposition whilst Portmann described laminated 'sand clay complexes' but offered no explanation of their genesis.

\section{Site descriptions}

\section{Bolterdalen}

At the eastern extreme of the fan which emanates from Bolterdalen $\left(78^{\circ} 10^{\prime} \mathrm{N} 16^{\circ} 2^{\prime} \mathrm{E}\right)$, lateral erosion of the Adventelva produces natural sections in both the fan materials and the bordering terrace feature. A typical succession in the fan front comprises approximately $1 \mathrm{~m}$ of poorly sorted gravels overlain by $<1 \mathrm{~m}$ of ripple laminated silty sand. The adjacent terrace feature, however, was shown to consist of $>3 \mathrm{~m}$ of sandy silts, horizontally laminated in the upper $1 \mathrm{~m}$. A well developed ice wedge polygon network exists within the terrace materials at this point and is exploited by thermokarst erosion in the vicinity of the river bank. Sections in these thermokarst gulleys reveal a similar sequence of horizontally laminated sandy silts.

\section{Damyra}

The area north of the road and south of the Adventelva between Endalen and Adventfjorden is occupied by a gently sloping topographic flat which rises to a maximum of $4.5 \mathrm{~m}$ above the river and is used as an airstrip by light aircraft. The northernmost edge of the terrace is strongly cliffed by fluvial erosion and exposes a maximum thickness of $>4.0 \mathrm{~m}$ of sandy silt. The presence of permafrost below approximately $1.5 \mathrm{~m}$ depth has enabled the river to erode deep thermo-erosional niches at the base of the cliff resulting in periodic block collapse of sections of bank up to $15 \mathrm{~m}$ long and $10 \mathrm{~m}$ wide. The exposure of undisturbed material in the 


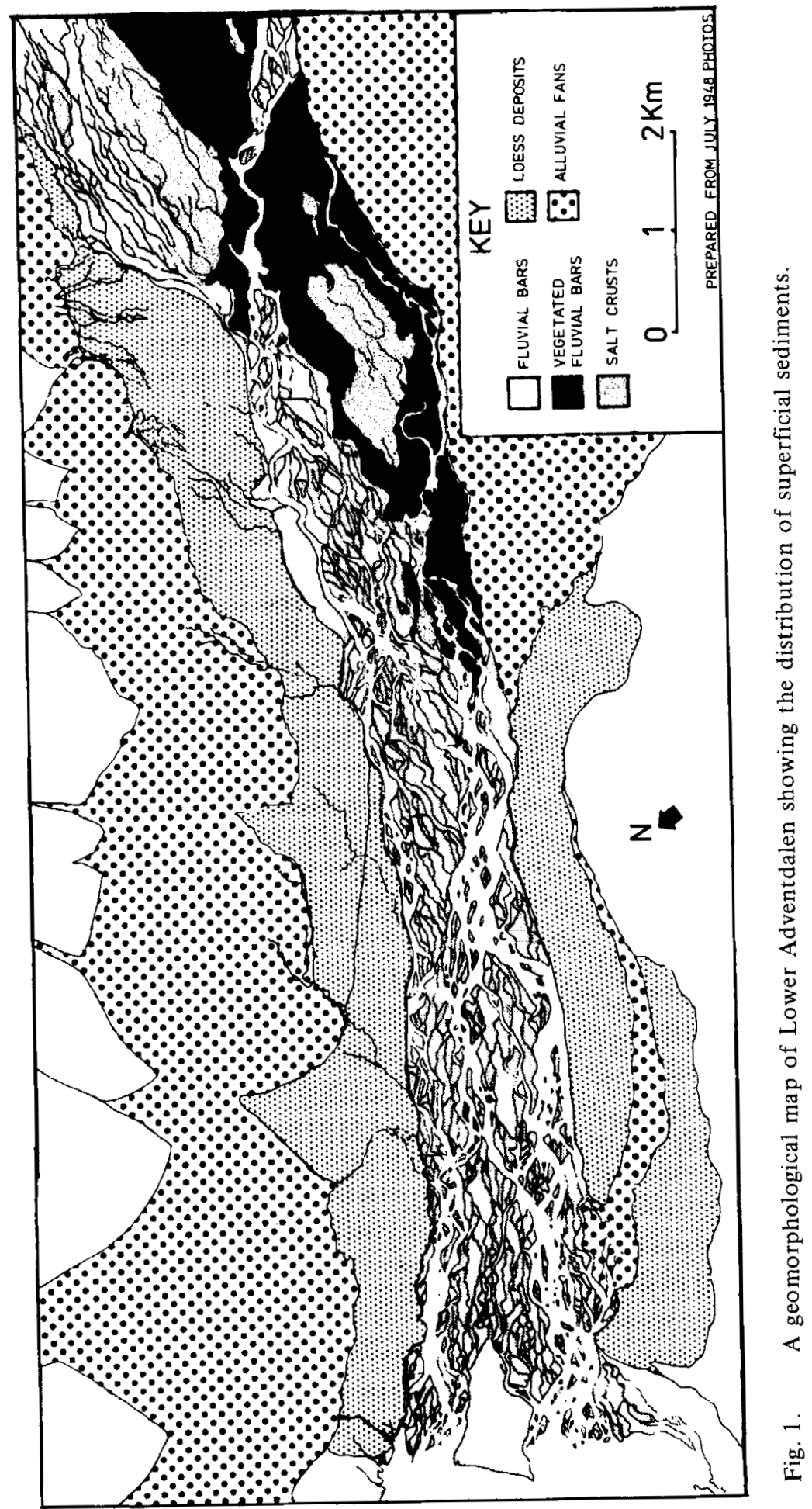




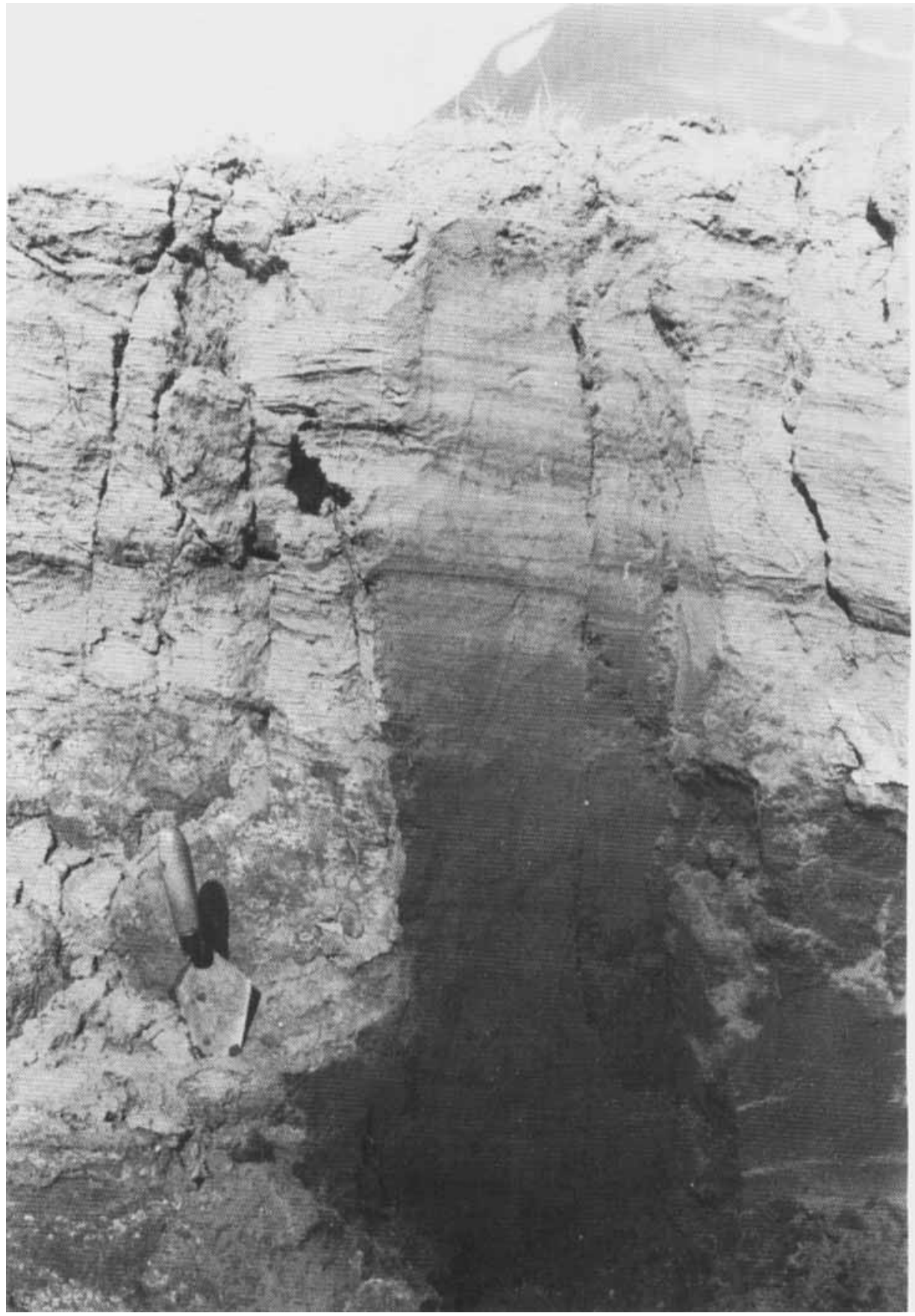

Fig. 2. Horizontally laminated sandy silt exposed in a rivercliff at $78^{\circ} 12^{\prime} \mathrm{N}, 15^{\circ} 46^{\prime} \mathrm{E}$. Trowel handle is $0.13 \mathrm{~m}$ long. 


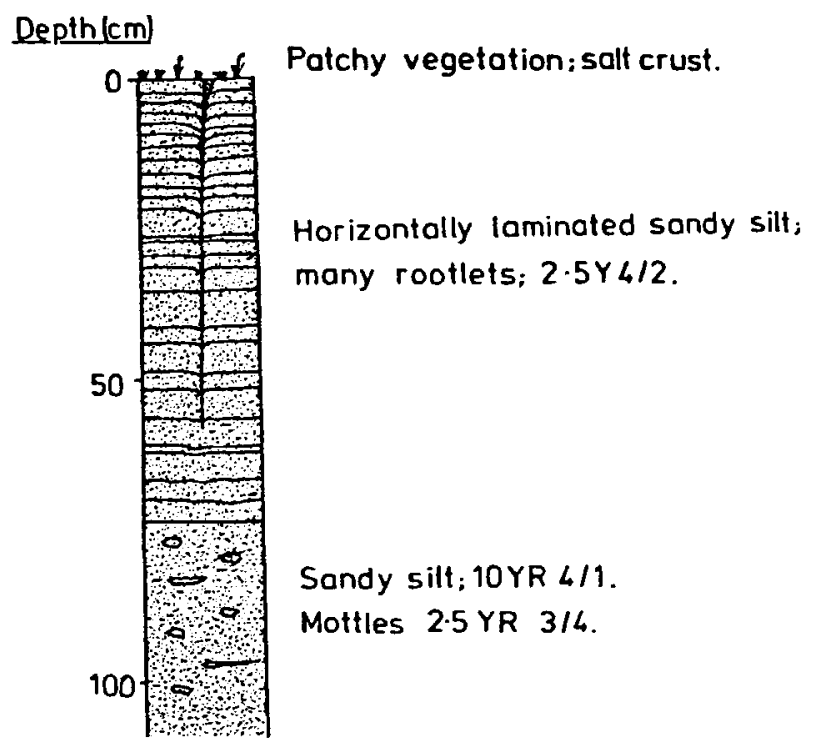

Fig. 3.

Profile description of the sediments illustrated in Fig. 2 .

backcliff of one such failure at $78^{\circ} 12^{\prime} \mathrm{N}, 15^{\circ} 46^{\prime} \mathrm{E}$ is shown in Figs. 2 and 3 . The surface of the terrace at this point is characterized by a well developed network of desiccation polygons 150 to $250 \mathrm{~mm}$ in diameter (Fig. 4). Where this crack network intersects vertical sections the lamination within the sands is downturned, substantiating the hypothesis that the crack pattern is a result of desiccation rather than freezing (WASHBURN 1979). A pit was excavated in the flat some $200 \mathrm{~m}$ southwest of the riverbank section and shown to possess similar characteristics.

Both of the terraces described above show a patchy vegetation cover of Salix herbacea L., sedges and mosses, and widespread salt crust formation. The salts were leached into the subsoil after heavy rain but reformed within 48 hours of the cessation of precipitation. Bulk samples from the natural section and the excavated section were collected for laboratory analyses.

Kubiena samples suitable for impregnation with resin and subsequent thin sectioning were collected from the cleaned vertical faces of the two river bank sections.

\section{Laboratory analyses}

\section{Textural characteristics}

Bulk samples of approximately $100 \mathrm{~g}$ of air dry sediment were subjected to standard pretreatment techniques to remove organic material and disaggregate clay particles. Grain size composition was then determined 


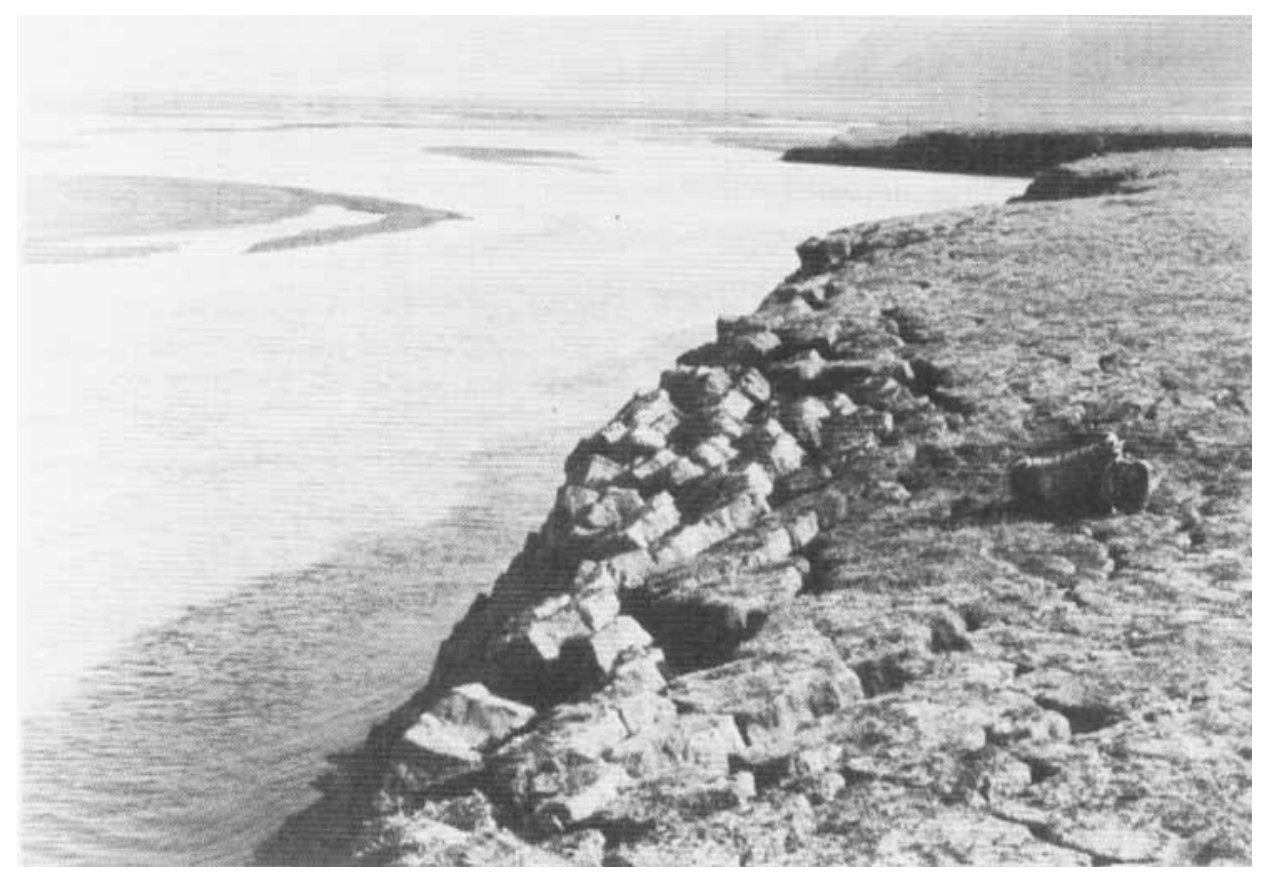

Fig. 4. The surface of the Damyra terrace at $78^{\circ} 12^{\prime} \mathrm{N}, 15^{\circ} 46^{\prime} \mathrm{E}$, looking upstream. The desiccation polygons have been tilted toward the river due to the development of a thermo-erosional niche in the underlying sediments. Unvegetated ripple topped bars, typical of the lowest reaches of the river, are visible just to the left hand side. Rucksack gives scale.

by dry sieving at $0.25 \phi$ intervals to $4.00 \phi$ and then by pipette analysis to $9.00 \phi$. The results (Fig. 5) are similar to those described from aeolian sediments from the northern side of the valley and from Bolterdalen (PORTMANN 1969). These sediments are texturally distinct from other superficial deposits described by Portmann and from floodplain sediment (Fig. 5). Grain size distribution, however, are rarely diagnostic of depositional processes in such environments (TUCKER and VACH-ER 1980) and so a variety of other characteristics were also examined.

\section{Particle microtextures}

A qualitative examination of grain surface textures using a scanning electron microscope showed a high proportion of the grains to possess upturned plates and adhering fine particulates (Fig. 6). Similar features have been described from loess deposits (CEGLA et al. 1971; NIETER and KRINSLEY 1976) although they may not be diagnostic. 


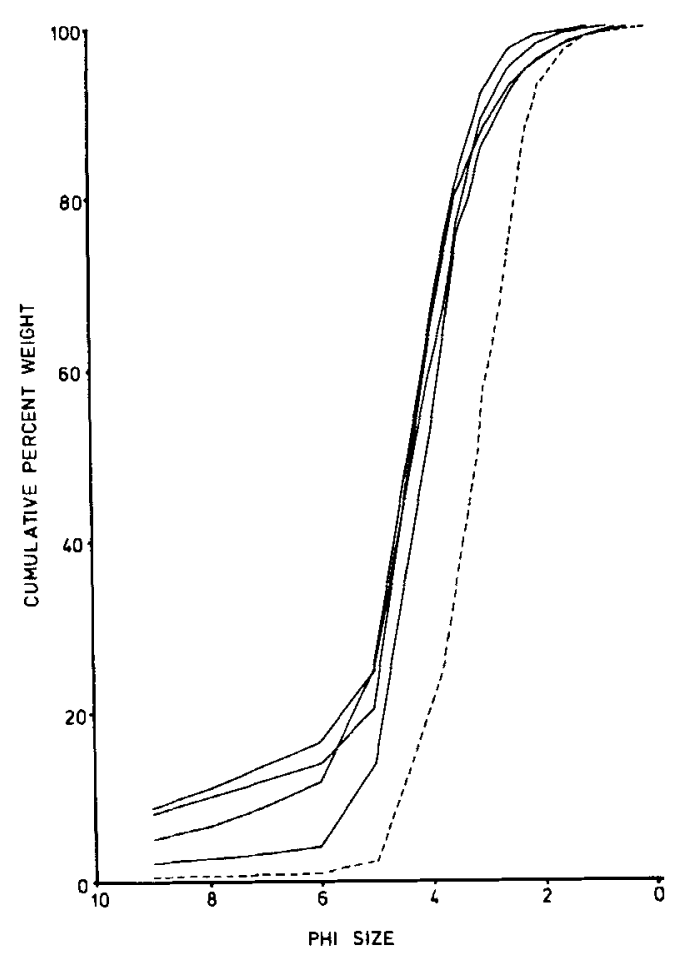

Fig. 5. Graphs to show the grain size composition of the sediments which underlie the marginal terraces. A sample of fluvially deposited overbank sediment is shown for comparison (hatched line).

\section{Solute content}

Solutes were extracted from sub-samples of the two bulk samples by leaching through a low ash content quantitative filter paper which nominally permitted material finer than $2 \mu \mathrm{m}$ to pass. Conductivity of these extracts varied between 428 and $590 \mu$ mhos ( 6 determinations). Interpretation of conductivity measurements is problematic but on the basis of data published by the U.S.D.A. (1954) these values suggest a dissolved salt concentration in the order of $60 \mathrm{meq}$ per $100 \mathrm{~g}$ of soil (cf. NICKLING 1978). FEDEROFF (1966) reports exchangeable base concentrations in the same materials of $17.8 \mathrm{meq}$ per $100 \mathrm{~g}$ of soil, of which $11.35 \mathrm{meq}$ was attributable to calcium and $4.7 \mathrm{meq}$ was attributable to sulphur, which suggests that the salt crusts were probably formed by calcium sulphate (gypsum). 


\section{Micromorphology}

Two thin sections were prepared from the Kubiena samples collected in the field. The skeletal grains exhibit a clearly preferred orientation. Lamination in the material is seen to result from alternations of poorly sorted and coarse bands of variable thickness with iron staining concentrated as coatings on the finer grains and therefore confined to the poorlysorted lamellae. The iron occurs primarily as haematitic coatings on the quartz grains rather than as ferriargillans since the clay content of the material in the thin sections is extremely low and as a result cutanic features are absent. The sections show a high proportion of organic material in the form of plant rootlets, a fact confirmed during the removal of organics by treatment with hydrogen peroxide (in preparation for grain size analysis), when up to $20 \%$ of the fresh weight of the sample was accounted for by organic material.

\section{Summary discussion}

It is suggested that the material comprising the terraces described above is loess on the basis of grain size composition, microfabric and microtexture. The absence of grains coarser than $-0.75 \emptyset$, together with the considerable height that the deposits reach above river level, suggests an aeolian origin.

This interpretation is also supported by field observations of active aeolian transport during the summer of 1980 and a variety of deflation phenomena observable on abandoned surfaces of fluvial deposits in the central area of the valley. Clouds of fine sediment could be seen to rise from abandoned areas of the central floodplain and be carried downwind for several kilometres throughout July 1980. The surfaces of such areas show a wide variety of deflation phenomena such as preferentially eroded ripple trains (cf. NICKLING 1978, Fig. 11) and deflation hollows. A further source of fine sediment is the area of ripple-topped longitudinal bars (cf.COLEMAN 1969) which characterise the lower reaches of the Adventelva between Endalen and Adventfjorden (Figs. 1 and 4). During late June and early July 1980 these bars were totally submerged but during the later part of July stage fell sufficiently to expose them and aeolian reworking of the bar surfaces then took place.

The valley marginal terraces would therefore appear to represent a proximal loess deposit most likely derived by deflation of fluvial sediments (cf. NICKLING 1978) and local redeposition (cf. FAHNESTOCK 1969; PEWE 1951, 1968; PISSART et al. 1978). The material possesses many of the characteristics of loess deposits described from North America and Europe (RUSSELL 1944; CEGLA et al. 1971), but is unusual 
in that it is characterized by horizontal mesoscale stratification in the upper metre. Horizontal lamination of aeolianites is discussed by GLENNIE (1970) and attributed to flattening of ripples due to increased flow strength as described by ALLEN (1968). High flow strengths in the boundary layer, however, seem unlikely to account for the observed lamination in Adventdalen since the accretionary surfaces are vegetated and it would seem that a reduction in the flow strength by roughness associated with the vegetation is the most likely cause of deposition.

Horizontal lamination of aeolian sediments on Banks Island is similar to that observed in Adventdalen and is attributed by PISSART et al. (1978) to reworking, during the spring melt, of material initially deposited on snow flanking the dry river bed. In Adventdalen, however, snow extends across the whole valley floor during the winter months and an alternative hypothesis is presented here to account for the observed lamination.



Fig. 6. Scanning electron micrograph of a quartz sand grain from the Damyra section showing a frosted surface and adhering fine particulates. 
Primary depositional units are poorly sorted with respect to particle diameter since the coarser grains tend to be coal particles which are larger than equivalent mass quartz particles due to their lower specific density. Salt crust formation appears to be of paramount importance in the initial stabilisation of these sediments. Since salt precipitation occurs first between larger grains (NICKLING 1978) any winnowing of the material subsequent to deposition will therefore preferentially remove the finer particles leaving a coarser lag on the surface of the original depositional unit. The later development of a vegetation mat appears to be the final phase in the stabilisation of these sediments (cf. PISSART et al. 1978). The breakdown of primary stratification below $0.73 \mathrm{~m}$ in the Damyra section (Fig. 3) and increase in mottling appears to coincide with approaching proximity to the permafrost table and therefore seems likely to be related to inhibition of drainage. The absence of any detectable fragipans or duripans and the breakdown of stratification below $0.73 \mathrm{~m}$ define the soil as a gleyed Arctic brown earth or Arctic cryochrept (SOIL SURVEY STAFF 1975). A similar profile described from $78^{\circ} 13^{\prime} \mathrm{N}$, $15^{\circ} 53^{\prime} \mathrm{E}$ by FEDEROFF (1966) defines this soil type as the Ugledal Series. This soil series is described from Adventdalen, Sassendalen, and Reindalen (FEDEROFF 1966). It might, therefore, be expected that similar aeolian accumulations are present in these and other valleys of Spitsbergen.

\section{Acknowledgements}

Accomodation was generously provided at the Vitenskapens Hus, Longyearbyen by Norsk Polarinstitutt. The assistance of officers of the Norsk Polarinstitutt is also gratefully acknowledged. The research was funded by the British Geomorphological Research Group, the Leonard Sutton Memorial Award, and the University of Reading. Dr. P. Worsley provided useful comments on an early draft of this manuscript.

\section{References}

ALLEN, J.R.L., 1968: Current ripples and their relation to patterns of water and sediment motion. North Holland, Amsterdam. $433 \mathrm{pp}$.

CEGLA, J., T. BUCKLEY, and I.J. SMALLEY, 1971: Microtextures of particles from some European loess deposits. Sedimentology 5: 129-134.

CHURCH, M., 1974: Hydrology and permafrost with reference to northern North America. In: Permafrost Hydrology, Proceedings of Workshop Seminar,

1974. Canadian National Committee, International Hydrological Decade, Environment Canada, Ottawa: 7-20. 
COLEMAN, J.M., 1969: Brahmaputra River: channel processes and sedimentation. Sediment. Geol. 3: 129-239.

FAHNESTOCK, R.K., 1969: Morphology of the Slims River. Icefield Ranges Research Project Scient. Results 1:161-172.

FEDEROFF, N., 1966: Les sols du Spitsberg occidental. In: Spitsberg 1964 et premieres observations 1965, Centre National de Recherche Scientifique, R.C.P. 42: 111-228. Audin, Lyon.

GLENNIE, K.W., 1970: Desert sedimentary environments. Developments in Sedimentology 14. 222 pp. Elsevier, Amsterdam.

NICKLING, W.G., 1978: Eolian sediment transport during dust storms: Slims River Valley, Yukon Territory. Can.J. Earth Sci. 15: 1069-1084.

NIETER, W.M. and D.H. KRINSLEY, 1976: The production and recognition of aeolian features on sand grains by silt abrasion. Sedimentology 23:713-720.

PEWE, T.L., 1951 : An observation on wind-blown silt. J. Geol. 59:399-401.

- $\quad 1968$ : Loess deposits of Alaska. XXII International Geological Congress 1968 8: 279-309.

PISSART, A., J.-S. VINCENT, and S.A. EDLUND, 1977: Depots et phenomenes eoliens sur l'ile de Banks, Territoires du Nord-Ouest, Canada. Can. J. Earth Sci. 14:2462-2480.

PORTMANN, J.-P., 1969: Some superficial deposits within the map sheet Adventdalen, Vestspitsbergen. Norsk Polarinstitutt Medd. Nr. 98.16 pp.

SOIL SURVEY STAFF, 1975: Soil taxonomy. U.S. Department of Agriculture, Agricultural Handbook 436. 754 pp.

TUCKER, R.W. and H.L. VACHER, 1980: Effectiveness of discriminating beach, dune and river sands by moments and the cumulative weight percentages. J. sedim. Petrol. 50: 165-172.

UNITED STATES DEPARTMENT OF AGRICULTURE, 1954: Diagnosis and improvement of saline and alkali soils. Agricultural Handbook 60.160 pp.

WASHBURN, A.L., 1979: Geocryology. Edward Arnold, London. 406 pp.

WILLIAMS, P.F. and B.R. RUST, 1969: The sedimentology of a braided river. $J$. Sediment. Petrol. 39: 649-679. 
